Jurnal Kejaora: Jurnal Kesehatan Jasmani dan Olah Raga

ISSN: 2541-5042 (Online)

ISSN: 2503-2976 (Print)

Volume 5 Nomor 1, Edisi April 2020

\title{
PENGEMBANGAN MEDIA GAWANG AYUN BADASPA DALAM PEMBELAJARAN SEPAKBOLA SISWA KELAS V MADRASAH IBTIDAIYAH (MI) SUGIHAN
}

\author{
Wahyu Bagus Santoso ${ }^{1,}$ Khamim Hariyadi² \\ 1,2 STKIP PGRI Trenggalek \\ Email: stkippgritrenggalek@yahoo.com¹, khamimhariyadi@gmail.com² \\ DOI: https://doi.org/10.36526/kejaora.v5i1.765
}

\begin{abstract}
ABSTRAK
Tujuan penelitian ini adalah untuk membuat pengembangan media gawang ayun badaspa dalam pembelajaran sepak Bola di (MI) Sugihan. Metode penelitian ini adalah penelitian pengembangan yang mengacu pada model ADDIE yaitu: Analisis, desain, development, implemantasi, dan evaluasi sedangkan teknik analisa data menggunakan skala likert. Populasi dalam penelitian ini adalah semua siswa kelas V (MI) Sugihan sebanyak 47 siswa. Dari hasil uji kelompok kecil didapat hasil rerata presentase $80,1 \%$ (baik), sedangkan dari uji kelompok besar didapat hasil rerata presentase $83,8 \%$ (baik), dari hasil validasi produk ahli pembelajaran sepakbola $90,0 \%$ (baik), dari hasil validasi ahli media pembelajaran $82 \%$ (baik), dan dari hasil evaluasi guru penjasorkes $97 \%$ (baik). Hasil dari pengembangan media pembelajaran yang dikembangkan sesuai dengan prosedur pengembangan didapat sebuah produk yang sesuai dengan kebutuhan peserta didik kelas V (MI) Sugihan adalah pengembangan media gawang ayun badaspa. Didapatkan kesimpulan bahwa pengembangan media gawang ayun badaspa dapat digunakan sebagai salah satu alternatif media pembelajaran untuk membantu kesulitan dalam pembelajaran sepakbola pada peserta didik kelas V (MI) Sugihan. Ini bisa dilihat dari 10 aspek yang muncul pada uji coba skala besar dan hasil evaluasi dari guru pendidikan olahraga dari 5 indikator yang muncul yaitu Indikator kesesuaian, kejelasan sajian, kemudahan akses, ketersediaan, berorientasi siswa dinyatakan baik.
\end{abstract}

Kata Kunci: Gawang Ayun Badaspa, Media, Pengembangan, Sepakbola, Pendidikan Jasmani

\section{PENDAHULUAN}

Pendidikan Jasmani pada dasarnya merupakan bagian integral dari sistem pendidikan secara keseluruhan, bertujuan untuk mengembangkan aspek kesehatan, kebugaran jasmani, keterampilan berfikir kritis, stabilitas emosional, keterampilan sosial, penalaran dan tindakan moral melalui aktivitas jasmani dan olahraga (Rahayu, 2016). Pendidikan jasmani bertujuan untuk mengembangkan aspek kesehatan, kebugaran jasmani, keterampilan berfikir kritis, stabilitas emosional, keterampilan sosial, penalaran dan tindakan moral melalui aktifitas jasmani dan olahraga (Fudin, 2016). "While the main problem facing physical education today is the change in cultural values, from the culture of motion to a culture of silence" (Pratama \& Febrianto, 2018). Dapat disimpulkan bahwa melalui pendidikan jasmani inilah diharapkan siswa mampu memperoleh pengalaman dalam hal sikap, pemikiran yang sportif, jujur, saling berbagi, disiplin, aktif maupun tanggung jawab itulah diantara tujuan diadakan pendidikan jasmani di sekolah.

Pendidikan jasmani dapat dibedakan dari dua sudut pandang, yaitu pandangan tradisional dan pandangan modern. Pandangan tradisional menganggap bahwa pendidikan jasmani hanya semata-mata mendidik jasmani atau sebagai pelengkap, penyeimbang, atau penyelaras pendidikan rohani manusia. Sedangkan pandangan modern atau sering disebut pandangan holistic, menganggap bahwa manusia bukan sesuatu yang terdiri dari bagian-bagian yang wajib diajarkan mulai dari jenjang yang terpilah-pilah (Tri \& Saputra, 2014).

Sepak bola berasal dari dua kata yaitu Sepak dan Bola. Sepak atau menyepak dapat diartikan menendang (mengumpan kaki) sedangkan bola yaitu alat permainan yang berbentuk bulat berbahan karet, kulit atau 
Jurnal Kejaora: Jurnal Kesehatan Jasmani dan Olah Raga

ISSN: 2541-5042 (Online)

ISSN: 2503-2976 (Print)

Volume 5 Nomor 1, Edisi April 2020

sejenisnya (Aji, 2016). Tujuan dari permainan sepak bola adalah memasukan bola sebanyak-banyaknya kegawang lawan dan berusaha menjaga gawangnya sendiri agar tidak kemasukan. Hal ini berarti salah satu regu dinyatakan menang apabila regu tersebut lebih banyak memasukan bola ke gawang lawannya atau lebih sedikit kemasukan bola. Jadi secara singkat pengertian sepak bola adalah suatu permainan yang dilakukan dengan cara menendang bola yang dilakukan oleh pemain, dengan sasaran gawang dan bertujuan memasukan bola ke gawang lawan. Dapat disimpulkan bahwa sarana dan prasarana pendukung untuk pembelajaran sepakbola di sekolah sangatlah penting untuk dikembangkan jika sekolah memiliki keterbatasan.

Berdasarkan observasi yang telah dilakukan oleh peneliti mendapatkan bahwa permainan sepakbola yang dilakukan masih terkendala atau tidak berjalan dengan sesuai apa yang diharapkan seperti sarana gawang. Tanpa adanya pengembangan media sarana gawang ketertarikan siswa dalam bermain sepakbola bisa dikatakan berkurang. Beberapa siswa cenderung kurang bergerak dengan kondisi lapangan yang kecil dan gawang seadanya akhirnya muncul siswa yang memiliki kemampuan lebih dibandingkan siswa lainnya.

Akibat dari kurangnya tersediannya sarana gawang maka perlu adanya pengembangan berupa media gawang ayun badaspa yaitu gawang yang dibuat dari pipa dimana gawang ini memiliki target tertentu untuk memperoleh poin. Dengan penambahan pengembangan media ini permainan sepakbola akan lebih menarik dan proses belajar mengajar bisa dilakukan dengan maksimal di Ml Sugihan. Pendekatan modifikasi dapat digunakan sebagai alternatif dalam pembelajaran pendidikan jasmani (Tri \& Saputra, 2014).

Beberapa penelitian sebelumnya yang berkaitan dengan permasalahan media pembelajaran diantaranya dipaparkan berikut ini. (Hartariani, Putu, Damayanthi, Wirawan, \& Sunarya, 2016) telah melakukan penelitian untuk mengetahui implemantasi media pembelajaran 3 dimensi dengan judul

"Pengembangan Media Pembelajaran 3 Dimensi Pada Mata Pelajaran Matematika Untuk Siswa Penyandang Tunagrahita" adapun Tahapan-tahapan yang digunakan adalah model ADDIE yaitu analysis, design, development, implementation dan evaluation. Rata-rata respon siswa terhadap pengembangan animasi 3 dimensi pada mata pelajaran matematika untuk siswa penyandang tunagrahita yaitu $90,7 \%$. Pengembangan media pembelajaran animasi 3 dimensi pada mata pelajaran matematika untuk siswa penyandang tunagrahita untuk siswa kelas D2 di SLB C Negeri Singaraja mampu menjadi sumber belajar bagi siswa

Dari permasalahan di atas dapat diartikan bahwa dengan mengembangankan media dapat digunakan sebagai suatu penyampaian dalam pembelajaran pendidikan jasmani. Oleh karenanya pengembangan media ini mempertimbangkan tahap-tahap perkembangan dan karakteristik anak, sehingga anak akan mengikuti pembelajaran pendidikan jasmani dengan senang dan gembira. Hal ini didukung oleh (Putra \& Fudin, 2019) A creative teacher will be able to create something new, or modify something that already exists but is presented in a more interesting way, so students do not feel bored.

Setelah perang, media televisi juga diterapkan dalam pendidikan sebuah genre baru program televisi muncul. Pengembangan sumber belajar ini sangatlah penting dilakukan oleh guru pendidikan jasmani dimanapun. Pengembangan adalah proses penerjemahan spesifikasi perancangan kedalam bentuk fisiknya (Dwiyogo, 203AD). Pengembangan memerlukan perancangan yang sistematis mengacu pada sistem pembelajaran, desain pesan, metode atau strategi dan memperhatikan karakteristik pelajar (Febrianto \& Puspitaningsih, 2020). Pengertian pengembangan media mengarah pada sesuatu yang mengantar/meneruskan imformasi (pesan) antara sumber (pemberi pesan) dan penerima pesan. Media adalah segala bentuk dan saluran yang dapat digunakan dalam suatu proses penyajian informasi. Media dapat berfungsi maksimal jika dapat diakses dengan mudah oleh 
Jurnal Kejaora: Jurnal Kesehatan Jasmani dan Olah Raga

ISSN: 2541-5042 (Online)

ISSN: 2503-2976 (Print)

Volume 5 Nomor 1, Edisi April 2020

penggunanya. Media yang terintegrasi dengan teknologi tercanggih belum tentu menjadi media yang terbaik (Putro, Kurniawan, Fudin, \& Trenggalek, 2018).

Dapat disimpulkan bahwa media adalah alat/cara yang digunakan sebagai perantara untuk menyampaikan informasi (pesan) agar dapat diterima oleh penerima informasi sepenuhnya. Sesuatu dikatakan sebagai media pembelajaran apabila mereka (media tersebut) digunakan untuk menyampaikan pesan dengan tujuan-tujuan pendidikan dan pembelajaran (Dwiyogo, 203AD). Hal ini diperkuat oleh (Kristiyanti, 2016) bahwa kemampuan guru dalam merancang dan menerapkan media pembelajaran merupakan kunci dari keberhasilan proses pembelajaran yang akhirnya hasil belajarpun sesuai harapan.

Berdasarkan hasil pengamatan pembelajaran sepakbola diperoleh informasi bahwa:

1. Lapangan di sekolah Ml sugihan tidak lebar.

2. Kurangnya pengembangan media gawang dalam pembelajaran sepakbola untuk menarik siswa siswi.

3. Guru olahraga kurang mengembangkan media pembelajaran

Dengan demikian pengembangan media gawang ayun badaspa bertujuan untuk pembelajaran siswa dan memanfaatkan media pembelajaran dengan keterbatasan sarana dan prasarana yang ada di Ml Sugihan.

\section{METODE}

Penelitian ini merupakan penelitian Pengembangan (Research and Development). Metode penelitian dan pengembangan adalah metode penelitian yang digunakan untuk menghasilkan produk tertentu, dan menguji keefektifan produk tersebut (Sugiyono, 2013). Teori ini juga didukung oleh (Maksum, 2012) bahwa penelitian pengembangan adalah penelitian yang bertujuan untuk mengembangkan suatu produk baru atau menyempurnakan produk yang telah ada.

Pada Penelitian ini peneliti menggunakan model ADDIE. Menurut (Branch, 2009) model pengembangan ADDIE 
Jurnal Kejaora: Jurnal Kesehatan Jasmani dan Olah Raga

ISSN: 2541-5042 (Online)

ISSN: 2503-2976 (Print)

Volume 5 Nomor 1, Edisi April 2020

\section{Development}

Tahap peneliti mengembangkan produk sesuai apa yang sudah direncanakan dalam tahap desain yaitu berupa media gawang ayun badaspa. Media gawang ayun badaspa didesain sesuai kebutuhan siswa, serta mempertimbangkan keamanan dan menarik untuk dibelajarkan kepada siswasiswi MI. Setelah produk jadi sebelum diuji cobakan, peneliti melakukan validasi kepada ahli media dan ahli pembelajaran apakah media ini sudah layak digunakan. Selanjutnya apabila mendapat saran dari para ahli maka peneliti melakukan revisi produk agar lebih sempurna sesuai masukan para ahli.

\section{Implementation}

Dalam tahap ini peneliti menerapakan apa yang sudah direncanakan dan dikembangkan untuk diuji cobakan kepada peserta didik, untuk mengetahui apakah media yang dikembangkan ini sudah sesuai apa yang direncanakan dan berguna untuk membantu proses pembelajaran. Dalam tahap uji coba produk peneliti melakukan dengan cara uji coba kelompok kecil dan uji coba kelompok besar.

\section{a. Uji Coba Kelompok Kecil}

Dalam melakukan uji coba produk awal ini dilakukan kepada siswa-siswi kelas $\mathrm{V}$ SDN 1 Ngares sebanyak 25 siswa. Dalam uji coba produk ini setelah melaksanakan pembelajaran dengan media gawang ayun ini maka peserta didik diberikan angket tertutup. Dengan angket ini maka peneliti bisa mengetahui kekurangan apa yang ada dalam media pembelajaran yang dikembangkan ini.

\section{b. Uji Coba Kelompok Besar}

Setelah direvisi sesuai hasil dari uji coba kelompok kecil maka peneliti melakukan uji coba kelompok besar dilakukan kepada siswa-siswi kelas V MI Madrasah Ibtidaiyah (MI) Sugihan sebanyak 47 siswa. Setelah melakukan maka peserta didik diberi angket tertutup supaya peneliti bisa mengetahui hasil media pembelajaran yang dikembangkan.

\section{Evaluation}

Tahap evaluasi merupakan tahapan akhir dari sebuah penelitian, pada tahap

evaluasi ini dari hasil uji coba kelompok besar yang berupa kuisioner dari guru penjas dan angket dari siswa, maka peneliti membuat kesimpulan berdasarkan hasil penelitian apakah media pembelajaran yang dikembangkan sudah berhasil sesuai dengan harapan peneliti. Dengan demikian peneliti mengetahui seberapa besar presentasi keberhasilan media gawang ayun badaspa yang dikembangkan peneliti.

Sumber data yang digunakan dalam penelitian ini berupa kuesioner untuk ahli pembelajaran sepakbola, kuesioner ahli media pembelajaran, angketr untuk siswa dan lembar evaluasi untuk guru Penjasorkes. Data dari pembelajaran sepakbola diperoleh saat validasi produk awal, sedangkan data dari siswa dan guru Penjasorkes diperoleh saat uji skala kecil (25 siswa) dan uji skala besar (47 siswa). Populasi dalam penelitian ini adalah semua seluruh siswa Madrasah Ibtidaiyah (MI) Sugihan berjumlah 240 siswa siswi dan sampel yang digunakan sebanyak 47 siswa siswi kelas V MI Sugihan.

Instrumen penelitian adalah alat-alat yang digunakan untuk memperoleh atau mengumpulkan data dalam rangka memecahkan masalah penelitian atau mencapai tujuan penelitian. Secara garis besar instrumen penelitian dalam pendidikan jasmani dan olahraga dapat dibedakan menjadi dua: tes dan non-tes. Instrumen tes berupa: (1) tes keterampilan, (2) tes tulis, dan (3) tes lisan, sedangkan yang non-tes berupa: (1) angket atau kuesioner, (2) interview, (3) observasi, dan (4) inventori (Winarno, 2013). Instrumen pada penelitian ini yang digunakan, yaitu: (1) Observasi dilakukan di MI Sugihan, dimana peneliti mengobservasi sarana olahraga yang ada di MI sugihan (2) Kuesioner dan angket dilakukan untuk memperoleh data terkait pengembangan Media gawan ayun badaspa.

Analisis data hasil penelitian dapat dibedakan menjadi dua bagian: analisis kualitatif dan analisis kuantitatif. Perbedaan ini tergantung pada jumlah dan sifat data yang dikumpulkan. Jika data yang diperoleh bersifat uraian yang tidak dapat diubah kedalam bentuk angka-angka, maka analisis datanya maka analisis datanya menggunakan analisis kualitatif. Sedangkan, 
Jurnal Kejaora: Jurnal Kesehatan Jasmani dan Olah Raga

ISSN: 2541-5042 (Online)

ISSN: 2503-2976 (Print)

Volume 5 Nomor 1, Edisi April 2020

jika data yang dikumpulkan dapat diklasifikasikan dalam kategori-kategori atau diubah dalam bentuk angka-angka, maka analisis data kuantitatif cocok digunakan (Winarno, 2013).

Dalam pengolahan data, persentase diperoleh dengan menggunakan Skala Likert. Skala likert digunakan untuk mengukur sikap, pendapat, dan persepsi seseorang atau sekelompok orang tentang fenomena sosial (Sugiyono, 2013).

Rumus untuk mengolah data yang berupa deskriptif persentase adalah sebagai berikut:

$$
P=\frac{F}{N} \times 100 \%
$$

Keterangan :

$$
\begin{array}{ll}
\mathrm{F} \quad \text { : } & \text { Frekuensi yang sedang dicari } \\
\text { persentasenya }
\end{array}
$$

Apabila datanya berupa persentase, proporsi maupun rasio, maka kesimpulan dapat diambil, disesuaikan dengan permasalahannya (Arikunto, 2014). Berikut ini penggolongan persentase kategori yang akan digunakan adalah:

a. Persentase kategori baik adalah $76 \%$ $100 \%$ digunakan

b. Persentase kategori cukup adalah $56 \%$ $75 \%$ digunakan

c. Persentase kategori kurang baik adalah $40 \%-55 \%$ tidak digunakan

d. Persentase kategori tidak baik adalah < $40 \%$ tidak digunakan

\section{HASIL DAN PEMBAHASAN}

Hasil penelitian dan pengembangan media gawan ayun badaspa dapat dijabarkan sebagai berikut:

\section{Hasil Penelitian \\ a. Analysis}

Dari hasil Analisis di MI Sugihan terkait pembelajaran bola besar pada materi sepak bola ada di kelas V semester 2, di kelas V MI Sugihan ada dua kelas yang siswanya kurang lebih ada 47 siswa. Sarana untuk

mempraktekan materi sepak bola belum mencukupi sehingga materi sepak bola tidak bisa dipraktikan karena tidak memiliki lapangan dan gawang sepak bola.

\section{b. Design}

Produk awal media gawang ayun ini untuk digunakan sebagai media pembelajaran materi sepak bola tingkat MI di MI Sugihan. Gawang ayun yang sudah jadi dengan spesifikasi ukuran yang telah ditentukan dan memiliki bobot yang ringan serta gawang ayun ini mudah dipindahkan dan mudah dalam penyimpanannya.

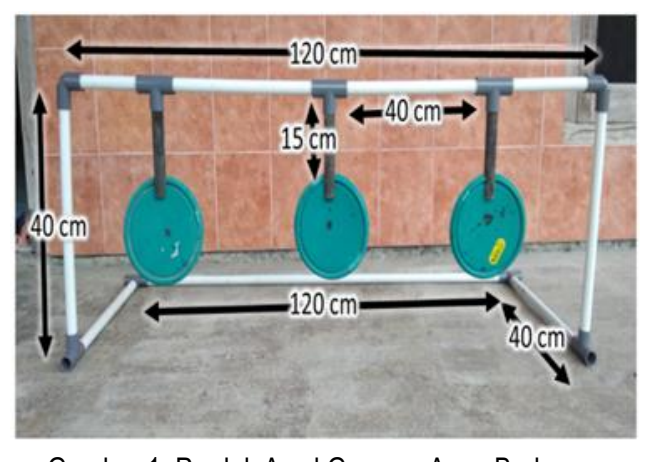

Gambar 1. Produk Awal Gawang Ayun Badaspa antara lain :

Media ini mermpunyai Spesifikasi

1. Panjang Gawang $120 \mathrm{~cm}$

2. Tinggi Gawang $40 \mathrm{~cm}$

3. Lebar gawang $40 \mathrm{~cm}$

4. Jarak Antar poin $40 \mathrm{~cm}$

5. Bahan dari pipa

Dari spesifikasi yang sudah dibuat ini muncul dari analisis peneliti saat ke MI Sugihan dimanan sarana dan prasarana disana kurang memadai untuk digunakan pembelajaran sepakbola. Dengan Spesifikasi Panjang 120, tinggi 40 dan lebar 40 dan terdapat poin pada gawang supaya media yang dipakai lebih mudah digunakan oleh siswa siswi MI Sugihan media gawang ayun yang dikembangkan ini bertujuan agar siswa lebih aktif dalam pembelajaran sepakbola.

\section{c. Development}

Adapun tahapan yang harus dilakukan untuk memperoleh media yang valid dan sesuai dengan materi pelajaran sebelum diimplementasikan adalah melalui tahap 
Jurnal Kejaora: Jurnal Kesehatan Jasmani dan Olah Raga

ISSN: 2541-5042 (Online)

ISSN: 2503-2976 (Print)

Volume 5 Nomor 1, Edisi April 2020

validasi ahli media pembelajaran dan ahli Sepak bola. Penilaian untuk ahli menggunakan kuisioner dimana kuisioner tersebut terdapat 5 indikator yaitu, 1) Kesesuaian, 2)Kejelasan sajian, 3) Kemudahan akses, 4) Ketersediaan, 5) Beroriantasi siswa dan hasil ini berupa persentase. Berikut ini adalah hasil pengisian kuesioner dari para ahli Media yang dituju.

Tabel 1. Validasi Produk Ahli Media Pembelajaran

\begin{tabular}{clccc}
\hline No & Indikator & Total & $\begin{array}{l}\text { Rata- } \\
\text { Rata }\end{array}$ & Persentase \\
\hline 1 & Kesesuaian & 12 & 4 & $80 \%$ \\
\hline 2 & $\begin{array}{l}\text { Kejelasan } \\
\text { Sajian }\end{array}$ & 13 & 4.3 & $86.7 \%$ \\
\hline 3 & $\begin{array}{l}\text { Kemudahan } \\
\text { Akses }\end{array}$ & 11 & 4 & $733 \%$. \\
\hline 4 & Ketersediaan & 8 & 4 & $80 \%$ \\
\hline 5 & $\begin{array}{l}\text { Berorentasi } \\
\text { Siswa }\end{array}$ & 18 & 4.5 & $90 \%$ \\
\hline \multicolumn{2}{c}{ Rata Rata } \\
\hline
\end{tabular}

Berdasarkan pada Tabel 1 validator memberikan Porsentase media yang divalidasi sangat baik pada indikator berorentasi pada siswa yaitu dengan persentasi $90 \%$, dengan rerata persentasi $82 \%$ meskipun dengan sedikit ada catatan dari validasi ahli media pembelajaran.

\begin{tabular}{llccc}
\multicolumn{5}{l}{ Tabel 2. Validasi Produk Ahli Sepak Bola } \\
\hline No & Indikator & Total & $\begin{array}{l}\text { Rata- } \\
\text { Rata }\end{array}$ & Persentase \\
\hline 1 & Kesesuaian & 14 & 4.7 & $93.3 \%$ \\
\hline 2 & $\begin{array}{l}\text { Kejelasan } \\
\text { Sajian }\end{array}$ & 13 & 4.3 & $86.7 \%$ \\
\hline 3 & $\begin{array}{l}\text { Kemudahan } \\
\text { Akses }\end{array}$ & 15 & 5 & $100 \%$ \\
\hline 4 & Ketersediaan & 8 & 4 & $80 \%$ \\
\hline 5 & $\begin{array}{l}\text { Berorentasi } \\
\text { Siswa }\end{array}$ & 18 & 4.5 & $90 \%$ \\
\hline \multicolumn{1}{c}{ Rata Rata } \\
\hline
\end{tabular}

Berdasarkan pada Tabel 2, validator memberikan Porsentase media yang divalidasi sangat baik pada indikator kemudahan akses yaitu dengan persentasi $100 \%$, dengan rerata prosentase $90 \%$ meskipun dengan cukup banyak catatan pada produk awal.

\section{d. Implementation}

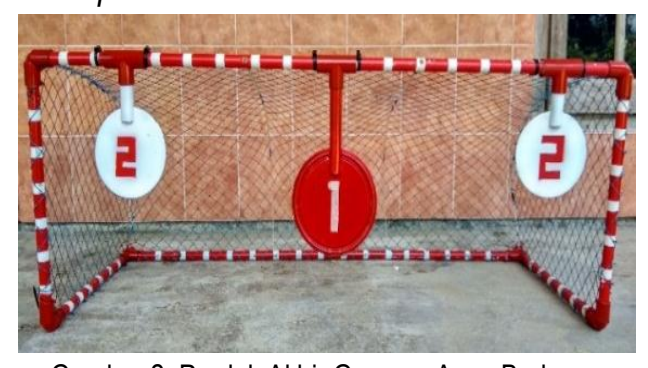

Gambar 2. Produk Akhir Gawang Ayun Badaspa

Oleh karena itu dapat dikatakan bahwa produk media gawang ayun badaspa dapat digunakan untuk uji coba kelompok kecil dan kelompok besar.

Tabel 3. Saran dan Revisi Ahli Media dan Ahli

\begin{tabular}{|c|c|c|c|c|}
\hline \multicolumn{5}{|c|}{ Sepakbola } \\
\hline No & Validator & $\begin{array}{l}\text { Bagian } \\
\text { yang } \\
\text { direvisi }\end{array}$ & $\begin{array}{l}\text { Alasan } \\
\text { direvisi }\end{array}$ & $\begin{array}{l}\text { Saran } \\
\text { perbaikan }\end{array}$ \\
\hline 1 & $\begin{array}{l}\text { Validator } \\
\text { Ahli } \\
\text { Sepakbola }\end{array}$ & $\begin{array}{l}\text { Kurang } \\
\text { menarik } \\
\text {, Kaki } \\
\text { kaki } \\
\text { gawang } \\
\text { tidak } \\
\text { kuat }\end{array}$ & $\begin{array}{l}\text { Warnany } \\
\text { a masih } \\
\text { polos, } \\
\text { tidak ada } \\
\text { jaring } \\
\text { gawang, } \\
\text { Gawang } \\
\text { mudah } \\
\text { bergeser } \\
\text { saat } \\
\text { terkena } \\
\text { bola }\end{array}$ & $\begin{array}{l}\text { Di cat } \\
\text { dengan } \\
\text { motif, } \\
\text { dityambah } \\
\text { kan jaring, }\end{array}$ \\
\hline 2 & $\begin{array}{l}\text { Validator } \\
\text { Ahli Media } \\
\text { Pembelaja } \\
\text { ran }\end{array}$ & $\begin{array}{l}\text { Warna } \\
\text { Gawang } \\
\text { Ayunan } \\
\text { Poin, } \\
\text { Bahan }\end{array}$ & $\begin{array}{l}\text { Warna } \\
\text { masih } \\
\text { polos, } \\
\text { Ayunan } \\
\text { Point } \\
\text { perlu } \\
\text { diberikan } \\
\text { angka } \\
\text { biar jelas, } \\
\text { bahan } \\
\text { perlu } \\
\text { yang } \\
\text { tidak } \\
\text { membah } \\
\text { ayakan }\end{array}$ & $\begin{array}{l}\text { Gunakan } \\
\text { warna } \\
\text { yang } \\
\text { menarik, } \\
\text { buat poin } \\
\text { target } \\
\text { dengan } \\
\text { jelas } \\
\text { berapa } \\
\text { saja } \\
\text { poinnya }\end{array}$ \\
\hline
\end{tabular}

Masukan yang berupa saran perbaikan, dan komentar terhadap draf media gawang ayun badaspa tersebut digunakan sebagai acuan untuk perbaikan draf model permainan target sebelum dilakukan uji lapangan.

\section{Uji Coba kelompok Kecil}

Uji skala kecil dilakukan pada siswa siswi SDN 1 Ngares kelas V. Tujuan uji kelompok kecil ini adalah untuk mengetahui tingkat implementasi media gawang ayun 
Jurnal Kejaora: Jurnal Kesehatan Jasmani dan Olah Raga

ISSN: 2541-5042 (Online)

ISSN: 2503-2976 (Print)

Volume 5 Nomor 1, Edisi April 2020

badaspa pada pembelajaran sepakbola. Data teknik analisis yang digunakan adalah prosentase untuk menganalisis dan penilaian dalam menilai tingkat kualitas produk terhadap produk media gawang ayun badaspa.

Tabel 4. Uji Coba Kelompok Kecil

\begin{tabular}{clcc}
\hline No & $\begin{array}{l}\text { Aspek Yang } \\
\text { Dinilai }\end{array}$ & $\begin{array}{l}\text { Hasil } \\
\text { Persentase }\end{array}$ & Keterangan \\
\hline 1 & $\begin{array}{l}\text { Membantu proses } \\
\text { belajar }\end{array}$ & $86 \%$ & Membantu \\
\hline 2 & $\begin{array}{l}\text { Kemenarikan } \\
\text { bentuk Media }\end{array}$ & $84 \%$ & Menarik \\
\hline 3 & $\begin{array}{l}\text { Kesenangan } \\
\text { dengan media }\end{array}$ & $79 \%$ & Senang \\
\hline 4 & $\begin{array}{l}\text { Kesukaan dengan } \\
\text { media }\end{array}$ & $76 \%$ & Suka \\
\hline 5 & $\begin{array}{l}\text { Kemudahan } \\
\text { mencetak skor }\end{array}$ & $82 \%$ & Mudah \\
\hline 6 & $\begin{array}{l}\text { Tendangan tidak } \\
\text { harus keras }\end{array}$ & $76 \%$ & Setuju \\
\hline 7 & $\begin{array}{l}\text { Usaha mencetak } \\
\text { skor }\end{array}$ & $84 \%$ & Butuh \\
\hline 8 & $\begin{array}{l}\text { Kesenangan } \\
\text { mencetak skor }\end{array}$ & $78 \%$ & Senang \\
\hline 9 & Keamanan media & $79 \%$ & Aman \\
\hline 10 & $\begin{array}{l}\text { Bisa tidaknya } \\
\text { memindahkan } \\
\text { media }\end{array}$ & $77 \%$ & Bisa \\
\hline Rata-rata & $80,1 \%$ & Baik \\
\hline & & \\
\hline
\end{tabular}

Berdasarkan pada tabel 4 penilaian terhadap media gawang ayun badaspa dari 10 indikator muncul bisa dikatakan "baik" dengan rata rata persentae $80.1 \%$. hal ini menunjukan bawha produk media yang dibuat dan diujikan pada kelompok kecil baik.

\section{Uji Coba Kelompok Besar}

Uji kelompok besar dilakukan pada siswa siswi MI Sugihan kelas V. Tujuan uji kelompok besar ini adalah untuk mencari saran dan penilaian terkait tingkat implementasi media gawang ayun badaspa pada pembelajaran sepakbola. Data teknik analisis yang digunakan adalah prosentase untuk menganalisis dan penilaian dalam menilai tingkat kualitas produk terhadap produk gawang ayun badaspa.

Tabel 5. Uji coba kelompok Besar

\begin{tabular}{clcc}
\hline No & $\begin{array}{l}\text { Aspek Yang } \\
\text { Dinilai }\end{array}$ & $\begin{array}{l}\text { Hasil } \\
\text { Persentase }\end{array}$ & Keterangan \\
\hline 1 & $\begin{array}{l}\text { Membantu proses } \\
\text { belajar }\end{array}$ & $88 \%$ & Membantu \\
\hline
\end{tabular}

\begin{tabular}{llcc}
\hline 2 & $\begin{array}{l}\text { Kemenarikan } \\
\text { bentuk Media }\end{array}$ & $87 \%$ & Menarik \\
\hline 3 & $\begin{array}{l}\text { Kesenangan } \\
\text { dengan media }\end{array}$ & $84 \%$ & Senang \\
\hline 4 & $\begin{array}{l}\text { Kesukaan dengan } \\
\text { media }\end{array}$ & $84 \%$ & Suka \\
\hline 5 & $\begin{array}{l}\text { Kemudahan } \\
\text { mencetak skor }\end{array}$ & $80 \%$ & Mudah \\
\hline 6 & $\begin{array}{l}\text { Tendangan tidak } \\
\text { harus keras }\end{array}$ & $79 \%$ & Setuju \\
\hline 7 & $\begin{array}{l}\text { Usaha mencetak } \\
\text { skor }\end{array}$ & $86 \%$ & Butuh \\
\hline 8 & $\begin{array}{l}\text { Kesenangan } \\
\text { mencetak skor }\end{array}$ & $90 \%$ & Senang \\
\hline 9 & Keamanan media & $83 \%$ & Aman \\
\hline 10 & $\begin{array}{l}\text { Bisa tidaknya } \\
\text { memindahkan } \\
\text { media }\end{array}$ & $79 \%$ & Bisa \\
\hline Rata-rata & $83,8 \%$ & Baik \\
\hline
\end{tabular}

Berdasarkan pada tabel 5 penilaian terhadap media gawang ayun badaspa dari 10 indikator muncul bisa dikatakan "baik" dengan rata rata persentae $83.8 \%$ ada peningkatan persentasi pada saat uji coba kelompok kecil, hal ini menunjukan bawha produk media yang dibuat dan diujikan pada kelompok besar baik.selain itu kritik dan saran yang diberikan dapat mengembangkan produk media gawang ayun badaspa menjadi lebih baik.

\section{e. Evaluation}

Berdasarkan pengamatan uji skala besar serta dari pengisian lembar evaluasi guru penjasorkes, mendapatkan kategori "baik" pada media gawang ayun badaspa dan dapat dikatakan media gawang ayun bisa digunakan sebagai alat bantu dalam pembelajaran sepakbola. Namun ada juga kelemahan dan kelebihan pada media gawang ayun ini yang dikemukanan oleh guru penjas saat melakukan evaluasi pada media gawang ayun yang sudah peneliti kembangkan antara lain :

1. Kelebihan

a. Media gawang ayun badaspa sangat menarik siswa siswi

b. Bahan yang didapat mudah dan murah.

c. Tidak memerlukan penjaga gawang.

d. Tidak membahayakan siswa siswa saat sedang melaksanakan pembelajaran sepakbola.

e. Gawang ayun tidak mudah rusak.

f. Dapat disimpan dengan mudah dan tidak memakan tempat. 
Jurnal Kejaora: Jurnal Kesehatan Jasmani dan Olah Raga

ISSN: 2541-5042 (Online)

ISSN: 2503-2976 (Print)

Volume 5 Nomor 1, Edisi April 2020

2. Kelemahan

a. Siswa masih harus meniti target poin pada gawang ayun badaspa jika ingin menang dengan poin tinggi.

b. Perlu satu paket dengan pengembangan bolanya.

c. Masih mudah goyang untuk gawang ayunnya.

d. Untuk poin target perlu sedikit lebih rendah dikarenakan bola harus menendang agak tinggi jika mau target poin.

\begin{tabular}{llccc}
\multicolumn{5}{c}{ Tabel 6. Evaluasi Guru Penjas } \\
\hline No & Indikator & Total & $\begin{array}{l}\text { Rata- } \\
\text { Rata }\end{array}$ & Persentase \\
\hline 1 & Kesesuaian & 15 & 5 & $100 \%$ \\
\hline 2 & $\begin{array}{l}\text { Kejelasan } \\
\text { Sajian }\end{array}$ & 14 & 4.7 & $93.3 \%$ \\
\hline 3 & $\begin{array}{l}\text { Kemudahan } \\
\text { Akses }\end{array}$ & 14 & 5 & $93.3 \%$ \\
\hline 4 & Ketersediaan & 10 & 5 & $100 \%$ \\
\hline 5 & $\begin{array}{l}\text { Berorentasi } \\
\text { Siswa }\end{array}$ & 20 & 5.0 & $100 \%$ \\
\hline \multicolumn{2}{c}{ Rata Rata } \\
\hline
\end{tabular}

Dengan mencermati hasil perhitungan pada uji coba kelompok kecil dan uji coba kelompok besar beserta evaluasi media yang berupa penilaian terhadap tingkat implementasi kelayakan media gawang ayun badaspa oleh siswa dan guru penjas. Maka etelah dihitung persentasenya, menunjuk bahwa pada uji coba kelompok kecik dikategorikan "Baik", untuk uji coba kelompok besar juga masuk dalam kategori "Baik" sedangkan hasil evaluasi guru penjasorkes juga dikategorikan "Baik".

Hal ini menunjukkan tingkat kelayakan implementasi media gawang ayun badaspa pada pembelajaran sepakbola di MI Sugihan tergolong dalam kategori "Baik/layak". Dengan demikian, media gawang ayun badaspa yang dikembangkan dapat menjadi salah satu alternatif bagi praktisi dalam upaya memaksimalkan pengembangan media dalam pembelajaran sepakbola di sekolah.

Hal ini diperkuat dengan penelitian terdahulu oleh (Hartariani et al., 2016) berjudul "Pengembangan Media Pembelajaran 3 Dimensi Pada Mata Pelajaran Matematika Untuk Siswa Penyandang Tunagrahita", dimana media pembelajaran yang digunakan sebagai panduan belajar siswa dapat meningkatkan

konsentrasi dan fokus pada anak serta membantu proses belajar siswa di sekolah.

\section{KESIMPULAN}

Dari uraian penelitian ini dapat ditarik kesimpulan yang sesuai dengan rumusan masalah. Hasil dari pengembangan media pembelajaran yang dikembangkan sesuai dengan prosedur pengembangan didapat sebuah produk yang sesuai dengan kebutuhan peserta didik kelas V Madrasah Ibtidaiyah (MI) Sugihan adalah pengembangan media gawang ayun badaspa. Disimpulkan bahwa pengembangan media gawang ayun badaspa dapat digunakan sebagai salah satu alternatif media pembelajaran untuk membantu kesulitan dalam pembelajaran sepakbola pada peserta didik kelas V Madrasah Ibtidaiyah (MI) Sugihan. Dapat dilihat dari 10 aspek yang muncul pada uji coba skala besar dan hasil evaluasi dari guru pendidikan olahraga dari 5 indikator yang muncul yaitu: Indikator kesesuaian, kejelasan sajian, kemudahan akses, ketersediaan, dan berorientasi siswa dinyatakan "Baik".

\section{UCAPAN TERIMA KASIH}

Ucapan terimakasih yang tak terhingga peneliti sampaikan kepada: Bapak Yudi Setiyono, S.H., M.H. selaku Ketua STKIP PGRI Trenggalek yang telah banyak memberikan arahan dan motivasi yang sangat diperlukan, Bapak Henri Gunawan Pratama, M.Pd. selaku Ketua Jurusan Prodi Pendidikan Jasmani yang telah memberikan kesempatan dalam penelitian dan penulisan artikel ilmiah ini. Kepala Sekolah MI Sugihan yang telah memberikan ijin untuk melakukan penelitian, serta guru Penjasorkes di MI Sugihan dalam memberikan konttribusinya selama penelitian.

\section{DAFTAR PUSTAKA}

Aji, S. (2016). Buku Olahraga Paling Lengkap (1st ed.). Pamulang: Ilmu Media.

Arikunto, S. (2014). Prosedur Penelitian (Suatu Pendekatan Praktik) (4th ed.). Jakarta: Rineke Cipta.

Branch, M. . (2009). Instructional Design : The ADDIE Aproach (1st ed.). New York: Springer. 
Jurnal Kejaora: Jurnal Kesehatan Jasmani dan Olah Raga

ISSN: 2541-5042 (Online)

ISSN: 2503-2976 (Print)

Volume 5 Nomor 1, Edisi April 2020

Dwiyogo, W. . (203AD). Pengembangan Sumber Belajar dalam Pembelajaran (1st ed.). Malang: Wineka Media.

Febrianto, R., \& Puspitaningsih, F. (2020). Pengembangan Buku Ajar Evaluasi Pembelajaran. Education Research and Development, 4(1), 1-18.

Fudin, M. . (2016). Upaya Meningkatkan Hasil Pembelajaran Lari Jarak Pendek denganPendekatan Permainan Tani dan Kancil. Jurnal Bravo's, 4(1), 2740.

Hartariani, L. L., Putu, L., Damayanthi, E., Wirawan, I. M. A., \& Sunarya, I. M. G. (2016). Pengembangan Media Pembelajaran 3 Dimensi Pada Mata Pelajaran Matematika Untuk Siswa Penyandang Tunagrahita. Pendidikan Teknologi Dan Kejuruan, 13(2), 137147.

Kristiyanti, N. (2016). Pengembangan Media Bolding ( Bola Bergelinding) Pada Mata Pelajaran IPS MAteri Kenampakan Alam, Sosial, dan Budaya Untuk Siswa Kelas IV Sekolah Dasar. Prosiding, 1-13. Semarang: UPGRIS.

Maksum, A. (2012). Metodologi Penelitian dalam Olahraga (1st ed.). Surabaya: Unesa University Press.

Pratama, Henri G, Febrianto R, H. K. (2018). Profile of Physical Fitness Level of Students-High School Students in Trenggalek Regency Based on TKJl. Journal of Physical Education, Sport, Health and Recreation, 7(3), 142-145.

Putra, R. E., \& Fudin, M. S. (2019). Development of Football Bowling Game for Football Learning Approaches. Active Journal of Physical Education, Sport, Health and Recreations, 8(3), 143-147.

Putro, B. N., Kurniawan, A., Fudin, M. S., \& Trenggalek, S. P. (2018). Pengembangan Buku Pedoman Man To Man Deffense Bola Basket Umtuk Pelatih. Sport Area, 3(2), 111-120.

Rahayu, E. T. (2016). Strategi Pembelajaran

Pendidikan Jasmani (2nd ed.).

Bandung: Alfabeta. 